\title{
PERILAKU STICKY COST BIAYA PENJUALAN, BIAYA ADMINISTRASI DAN UMUM SERTA HARGA POKOK PENJUALAN PADA PERUSAHAAN MANUFAKTUR
}

\author{
Lea Ratnawati \\ Fakultas Ekonomika dan Bisnis, Universitas Kristen Satya Wacana \\ Yeterina Widi Nugrahanti \\ Fakultas Ekonomika dan Bisnis, Universitas Kristen Satya Wacana \\ yeterina.nugrahanti@staff.uksw.edu
}

\begin{abstract}
The objective of this study is to find the indication of sticky cost behavior in Indonesian manufacturing. The cost stickiness can be indicated by asymetric reaction of costs to changes. This study employs Anderson, Banker, Janakiraman $(A B J)$ model to identify the sticky cost behaviour on selling expense and general administrative expense. The samples of this study are 351 firm years of manufacturing companies listed in Indonesia Stock Exchange during 2009-2012. This study found that selling, general and administrative cost increase 0,475 percent and cost of good sold increase 1,063 percent when sales increase 1 percent. Whereas, the sales and selling, general and administrative cost decrease 0,409 percent and cost of good sold decrease 0,033 percent per1 percent decrease in sales. The research results provide of sticky cost behaviour indication in selling expense, general and administrative, and cost of good sold in Indonesian manufacturing company. The findings support the theory of cost adjustment delay.
\end{abstract}

Keywords: sticky cost, selling, general and administrative costs, cost of good sold, net sales

\section{PENDAHULUAN}

Perilaku biaya menjelaskan hubungan antara biaya dengan aktivitas. Perilaku biaya dimanfaatkan manajer untuk memprediksi apa yang akan terjadi di masa mendatang pada pos-pos biaya dalam setiap aktivitas operasi (Banker dan Chen 2006). Perilaku biaya akan menyesuaikan perubahan volume sumber daya yang sudah direncanakan manajer, sedangkan volume sumber daya dipengaruhi permintaan konsumen (Anderson et al., 2003). Manajer perlu berhati-hati dalam perencanaan sumber daya, yaitu menunda pemanfaatannya sampai mendapat kepastian permintaan yang turun (Malcolm 1991).

Dalam model tradisional, cost dideskripsikan sebagai fixed cost dan variable cost yang berhubungan dengan tingkat perubahan volume aktivitas. Secara umum 
diasumsikan bahwa variable cost berubah secara proporsional terhadap tingkat perubahan volume aktivitas. Sementara fixed cost secara konstan tidak berubah dan tidak terpengaruh oleh tingkat perubahan volume aktivitas (Argiles dan Blandon 2009). Dua jenis biaya di atas adalah komponen penyusun total biaya suatu perusahaan. Bila komponen fixed cost dalam total biaya suatu perusahaan tersebut lebih tinggi daripada variable cost, maka akan memunculkan perilaku sticky cost (Malcolm 1991).

Suatu biaya dikatakan sticky ketika kenaikan biaya lebih besar dibandingkan dengan penurunannya pada perubahan aktivitas dengan jumlah yang ekuivalen. Perilaku sticky cost menghasilkan penyesuaian biaya yang kecil ketika penjualan menurun, sehingga yang mengakibatkan penghematan biaya menjadi rendah. Dengan demikian ketika penjualan menurun dan biaya menjadi tetap atau sticky, maka laba yang diperoleh menjadi berkurang. Sehingga jika tingkat sticky cost semakin tinggi, maka perusahaan membutuhkan volume aktivitas penjualan yang semakin tinggi untuk memperoleh laba (Weiss 2010).

Penelitian tentang sticky cost pernah dilakukan oleh Anderson et al. (2003) serta Weidenmier dan Subramaniam (2003) di USA; De Medeiros dan Costa (2005) di Brazil; Teruya et al. (2010) dan Weiss (2010) di Jepang. Secara keseluruhan, hasil penelitian tersebut menyimpulkan adanya perilaku sticky pada biaya penjualan, administrasi dan umum. Adanya perilaku sticky cost dapat mengurangi tingkat akurasi peramalan laba. Selain itu, Weidenmier dan Subramaniam (2003) juga menemukan indikasi sticky cost pada harga pokok penjualan (HPP).

Penelitian tentang sticky cost juga pernah dilakukan di Indonesia. Windyastuti dan Biyanto (2005) serta Hidayatullah et al. (2011) menemukan adanya perilaku sticky cost pada biaya penjualan, administrasi dan umum di perusahaan manufaktur. Sedangkan Nugroho dan Endarwati (2013) menemukan bahwa tidak terdapat indikasi perilaku sticky cost pada perusahaan manufaktur di Indonesia. Adapun Hidayatullah et al. (2011) menemukan bahwa HPP tidak bersifat sticky.

Hasil penelitian Anderson (2003), De Medeiros dan Costa (2005), Teruya (2010), Weiss (2010), Windyastuti dan Biyanto (2005) serta Weidenmier dan Subramaniam (2003) menemukan adanya sticky cost pada biaya penjualan, administrasi serta umum dan HPP. Sedangkan hasil penelitian Nugroho dan Endarwati (2013) dan Hidayatullah et al. (2011) tidak menemukan indikasi perilaku sticky cost pada biaya penjualan, administrasi dan umum serta HPP. Berdasarkan penelitian sebelumnya dengan hasil yang berbeda-beda, maka penelitian ini perlu dilakukan lagi untuk membuktikan perilaku sticky cost pada biaya penjualan, administrasi dan umum serta HPP dengan menggunakan data yang lebih terkini.

Penelitian ini dilakukan pada perusahaan sektor manufaktur di Bursa Efek Indonesia (BEI) dari periode 2009-2012. Penelitian ini berfokus pada biaya penjualan, administrasi dan umum serta HPP, karena pos-pos biaya ini merupakan 
komponen biaya terbesar yang erat kaitannya dalam aktivitas operasi dan produksi perusahaan manufaktur. Jika dibandingkan dengan perusahaan dagang dan jasa, perusahaan manufaktur memiliki fungsi bisnis yang lebih kompleks. Perusahaan manufaktur adalah perusahaan yang mengolah barang jadi terlebih dahulu dan kemudian menjualnya. Dalam melakukan proses produksi, perusahaan manufaktur memerlukan elemen-elemen lain yang nantinya akan memengaruhi harga jual barang jadi seperti persediaan bahan baku, tenaga kerja, overhead pabrik dan elemen produksi lainnya yang membentuk variabel HPP.

Indikasi sticky cost pada biaya penjualan, administrasi dan umum serta HPP akan terlihat pada saat mengamati respon dari biaya penjualan, administrasi dan umum serta HPP terhadap perubahan penjualan bersih, dan mendiskriminankannya dengan periode penjualan naik dan periode penjualan turun. Penjualan bersih dipilih sebagai driver dari proksi aktivitas perusahaan yang tidak dapat teramati secara langsung (Cooper dan Kaplan 1998).

Penelitian ini bertujuan untuk menyajikan bukti empiris indikasi perilaku sticky cost pada biaya penjualan, administrasi dan umum serta HPP di perusahaan manufaktur. Hasil penelitian ini bermanfaat sebagai referensi pengembangan literatur mengenai perilaku biaya, terutama perilaku sticky cost. Hasil penelitian ini juga diharapkan menjadi masukan bagi perusahaan manufaktur di Indonesia khususnya manajer dalam mempertimbangkan pengambilan keputusan dan perencanaan biaya apabila sticky cost terbukti terjadi pada perusahaan.

\section{TELAAH LITERATUR DAN PERUMUSAN HIPOTESIS}

\section{Sticky Cost}

Dalam akuntansi biaya disebutkan bahwa biaya dan volume aktivitas memiliki hubungan yang simetris. Namun Malcolm (1991) menemukan bahwa terdapat biaya yang cenderung kaku dan tetap melekat ketika aktivitas meningkat, bahkan ketika terjadi penurunan aktivitas. Ini dikarenakan terdapat beberapa biaya yang tidak sepenuhnya sebanding dengan perubahan aktivitasnya. Biaya ini dikenal sebagai sticky cost.

Indikasi perilaku sticky cost akan terlihat pada perubahan biaya yang tidak proporsional saat aktivitas penjualan meningkat dan menurun. Anderson et al. (2006) menyatakan bahwa sticky cost muncul sebagai akibat dari manajer yang cenderung untuk menunda upaya pengurangan sumber daya sampai diperoleh kepastian tentang permintaan yang menurun.

Sticky cost muncul akibat keputusan yang disengaja dan penyesuaian yang ditunda oleh manajer (Yasukata dan Kajiwara 2011). Masalah penelitian tersebut diuji dengan cost adjustment delay theory. Manajer yang memprediksi penjualan akan meningkat di masa depan akan mengambil keputusan untuk mempertahankan 
sumber daya yang tidak digunakan daripada melakukan penyesuaian biaya ketika permintaan menurun. Dengan demikian hal ini akan menimbulkan biaya tetap yang membuat total biaya sulit untuk berubah sehingga muncul indikasi perilaku sticky cost.

Weiss (2010) juga menemukan bahwa besaran sticky cost dalam perusahaan memiliki pengaruh terhadap pendapatan penjualan perusahaan. Perusahaan yang memiliki tingkat sticky cost yang tinggi menyebabkan pendapatan penjualan menurun karena aktivitasnya juga menurun dan biaya tetapnya tinggi, sehingga jika perusahaan boros maka akan terjadi inefisiensi dan laba di tahun ini atau di tahun yang akan datang tidak dapat diprediksi dengan tepat.

\section{Perilaku Sticky Cost pada Biaya Penjualan, Administrasi dan Umum}

Perubahan biaya berhubungan dengan perubahan volume sumber daya yang dipengaruhi oleh permintaan yang fluktuatif, sehingga hal ini memengaruhi pertimbangan manajer untuk mengambil keputusan di masa yang akan datang. Manajer cenderung tidak akan mengurangi sumber daya ketika perekonomian belum tumbuh sesuai prediksi sehingga perilaku sticky cost lebih tinggi (Anderson 2003).

Pada kondisi dimana komponen terbesar dalam biaya penjualan, administrasi dan umum adalah fixed cost, maka biaya tidak akan mudah mengikuti pergerakan penjualan. Dapat pula disimpulkan bahwa kenaikan biaya penjualan, administrasi dan umum ketika penjualan naik, lebih besar dibandingkan dengan penurunannya pada volume yang sama (Anderson et al., 2006).

Biaya tidak berubah secara proporsional dengan perubahan aktivitas saat sticky cost terjadi karena ketidakseimbangan penyesuaian sumber daya. Manajer dengan sengaja membuat keputusan untuk menunda penyesuaian sumber daya ketika aktivitas menurun dibanding penyesuaian sumber daya ketika aktivitas meningkat. Biaya terjadi karena manajer tetap memakai sumber daya yang tak terpakai, daripada melakukan penyesuaian ketika volume aktivitas menurun (Hidayatullah et al., 2011).

Komponen pembentuk biaya penjualan, administrasi dan umum antara lain biaya gaji karyawan kantor, biaya penyusutan gedung kantor dan pemeliharaan aset kantor. Penghentian karyawan kantor ketika penjualan menurun pada perusahaan akan berakibat kekurangan tenaga kerja ketika penjualan meningkat, sehingga membuat cost penggantian tenaga kerja atau biaya gaji karyawan kantor naik. Dalam hal ini, perilaku sticky cost akan menjadi lebih tinggi. Perilaku sticky cost juga terjadi ketika penjualan meningkat, sehingga biaya pemeliharaan aset juga ikut meningkat seiring peningkatan kapasitas penggunaan. Tetapi ketika penjualan menurun, maka perusahaan pun mengeluarkan biaya pemeliharaan aset untuk mempertahankan aset jika sewaktu-waktu penjualan meningkat dan tidak mungkin dilakukan penghentian aset begitu saja. Contohnya peralatan mesin kantor seperti komputer, mesin fotokopi dan mesin-mesin kantor yang digunakan dalam aktivitas penjualan perusahaan (Windyastuti dan Biyanto 2005). 
Weidenmier dan Subramaniam (2003) menyatakan bahwa biaya penjualan, administrasi dan umum meningkat sebesar 0,7 persen untuk setiap kenaikan 1 persen pada pendapatan. Akan tetapi biaya penjualan serta administrasi dan umum menurun sebesar 0,58 persen untuk setiap penurunan 1 persen pada pendapatan. Hasil ini konsisten dengan penelitian Anderson et al. (2003) yang menunjukkan perilaku sticky cost pada biaya penjualan, administrasi dan umum.

Hasil penelitian Hidayatullah et al. (2011) menunjukkan ketika penjualan bersih turun sebesar 1 persen maka biaya penjualan, administrasi dan umum akan turun sebesar 0,329 persen. Sedangkan ketika penjualan bersih mengalami kenaikan sebesar 1 persen, maka biaya penjualan, administrasi dan umum akan naik sebesar 0,501 persen.

Windyastuti dan Biyanto (2005) menemukan ketika penjualan bersih turun sebesar 1 persen, maka biaya penjualan serta administrasi dan umum akan turun sebesar 0,08 persen. Sedangkan bila penjualan bersih mengalami kenaikan sebesar 1 persen, maka biaya penjualan, administrasi dan umum akan naik sebesar 0,68 persen. Variasi biaya penjualan, administrasi dan umum ketika penjualan bersih mengalami kenaikan lebih besar daripada penurunan biaya ketika penjualan bersih mengalami penurunan. Dari pernyataan diatas dirumuskan hipotesis sebagai berikut.

H1: Besaran kenaikan biaya penjualan, administrasi dan umum pada saat penjualan bersih naik lebih tinggi dibanding besaran penurunan biaya penjualan, administrasi dan umum pada saat penjualan bersih turun.

\section{Perilaku Sticky Cost pada Harga Pokok Penjualan}

Dalam akuntansi biaya, terdapat dua metoda perhitungan harga pokok yaitu full/absorption costing dan variable/direct costing. Perbedaan pokok diantara kedua metoda tersebut adalah terletak pada perlakuan terhadap biaya produksi yang bersifat tetap. Pada variable costing, yang dimasukkan sebagai komponen HPP hanya biaya produksi yang variabel saja. MetodA full costing memperhitungkan seluruh komponen biaya produksi sebagai unsur harga pokok baik yang bersifat variabel maupun tetap. Penggunaan metodA full costing dalam menghitung dan menentukan harga jual suatu produk akan menghasilkan informasi yang tepat dan akurat, sehingga sinyal indikasi perilaku sticky cost dapat diuji (Mulyadi 2005). Pada penelitian ini, HPP yang dimaksud adalah HPP yang dihitung dengan full costing.

Perhitungan harga pokok produksi merupakan salah satu faktor penting dalam menentukan HPP yang harus dilakukan dengan mengefisienkan biaya-biaya yang dibutuhkan untuk memproduksi barang jadi (Setiawan dan Edison 2008). Efisiensi sangat erat terkait dengan laba, sehingga manajer dituntut untuk bersikap efisien dan efektif dalam membuat perencanaan biaya serta penyesuaian sumber daya karena adanya ketidakpastian permintaan di masa yang akan datang (Hidayatullah et al., 2011). 
Dalam perusahaan manufaktur, HPP ditentukan oleh beberapa elemen harga pokok produksi seperti biaya bahan baku, biaya tenaga kerja langsung dan biaya overhead pabrik (biaya tenaga kerja tidak langsung, biaya penolong, biaya penyusutan, biaya pemeliharaan atau reparasi, listrik, air, telepon dan lain-lain). Biaya-biaya tersebut timbul ketika perusahaan melakukan proses produksi dari persediaan bahan baku yang kemudian dikelola dengan bahan pembantu untuk menghasilkan barang jadi yang bernilai jual (Melina 1997).

Ketika permintaan meningkat, maka manajer memutuskan untuk menambah kapasitas produksi, sehingga elemen-elemen pembentuk HPP juga akan meningkat. Namun ketika permintaan menurun, maka manajer akan meminimalkan biaya produksi, tetapi tidak seluruh biaya akan turun mengikuti aktivitas produksi. Sebagai contoh biaya overhead pabrik, ketika produksi turun ada kemungkinan manajer tetap mempekerjakan tenaga pabrik untuk berjaga-jaga jika ada kenaikan produksi di periode mendatang, manajer juga akan tetap melakukan pemeliharaan mesin, pemeliharaan gudang dan peralatan pabrik (Weiss 2010).

Penelitian Weidenmier dan Subramaniam (2003) menemukan bahwa HPP meningkat sebesar 1,01 persen untuk setiap kenaikan 1 persen pada pendapatan, sedangkan HPP berkurang 0,94 persen untuk setiap penurunan 1 persen pada pendapatan. Hasil ini memberikan bukti perilaku perilaku sticky cost pada HPP. Dari uraian diatas, dirumuskan hipotesis sebagai berikut.

H2: Besaran kenaikan HPP pada saat penjualan bersih naik lebih tinggi dibanding besaran penurunan HPP pada saat penjualan bersih turun.

\section{METODA PENELITIAN}

\section{Populasi dan Sampel}

Populasi penelitian ini adalah perusahaan-perusahaan sektor manufaktur yang terdaftar di Bursa Efek Indonesia untuk periode 2009-2012. Teknik pengambilan data dilakukan dengan metoda purposive sampling dengan kriteria sebagai berikut.

1. Perusahaan sektor manufaktur yang tercatat pada Bursa Efek Indonesia periode tahun 2009 hingga 2012 secara terus menerus.

2. Perusahaan sektor manufaktur yang mencatat biaya penjualan, administrasi dan umum, HPP serta penjualan bersih dari tahun 2009 hingga 2012.

3. Biaya penjualan, administrasi dan umum serta HPP tidak melebihi pendapatan penjualan bersih. 


\section{Teknik Analisis}

\section{Model Sticky Cost}

Anderson et al. (2003) menggunakan sebuah model yang diberi nama Anderson, Banker, Janakiraman (ABJ) untuk menemukan indikasi perilaku sticky cost pada biaya penjualan serta biaya administrasi dan umum. Model ini selanjutnya akan digunakan untuk melihat perilaku sticky cost pada biaya penjualan, administrasi dan umum serta HPP terhadap perubahan dari penjualan bersih dan mendiskriminankannya antara periode pendapatan penjualan naik dan periode pendapatan penjualan menurun. Interaksi antara variabel decreased dummy (DECRDUM) mengambil nilai 1 jika pendapatan penjualan menurun selama periode t-1 dan t (tahun 2009-2010, 2010-2011 dan 2011-2012), dan nilai 0 jika sebaliknya (Hidayatullah et al., 2010).

Pengujian H1:

$\log \left[\frac{P A \& U_{i, t}}{P A \& U_{i, t-1}}\right]=\beta_{0}+\beta_{1} \log \left[\frac{\text { Revenue }_{i, t}}{\text { Revenue }_{i, t-1}}\right]+\beta_{2} * \operatorname{DECRDUM}_{i, t} * \log \left[\frac{\text { Revenue }_{i, t}}{\text { Revenue }_{i, t-1}}\right]+$

Keterangan:

$\mathrm{PA} \& \mathrm{U}_{\mathrm{i}, \mathrm{t}} \quad=$ Biaya penjualan, administrasi dan umum perusahaan i periode $\mathrm{t}$.

Revenue $_{\mathrm{i}, \mathrm{t}} \quad=$ Pendapatan penjualan bersih perusahaan i pada periode $\mathrm{t}$.

DECRDUM $M_{\mathrm{i}, \mathrm{t}} \quad=$ Variabel dummy periode penjualan yang bernilai 1 jika penjualan turun dan bernilai 0 jika penjualan naik.

Jika biaya penjualan, administrasi dan umum (PA\&U) adalah sticky, variasi biaya penjualan, administrasi dan umum dengan penjualan bersih (revenue) bertambah harus lebih besar daripada ketika penjualan bersih menurun. Koefisien $\beta_{1}$ mengukur persentase kenaikan biaya penjualan, administrasi dan umum akibat kenaikan penjualan bersih sebesar 1 persen. Sedangkan penjumlahan koefisien $\beta_{1}+\beta_{2}$ mengukur persentase penurunan biaya penjualan, administrasi dan umum akibat penurunan penjualan bersih sebesar 1 persen.

Hipotesis 1 mendasarkan pada asumsi $\beta_{1}>0, \beta_{2}<0$, atau jika $\beta_{1}+\beta_{2}<\beta_{1}$, yang menunjukkan bahwa kenaikan biaya penjualan, administrasi dan umum pada saat penjualan bersih naik lebih tinggi dibandingkan penurunan biaya penjualan, administrasi dan umum pada saat penjualan bersih turun. Ini berarti biaya penjualan, administrasi dan umum bersifat sticky. 
Pengujian H2:

$\log \left[\frac{H P P_{i, t}}{H P P_{i, t-1}}\right]=\beta_{0}+\beta_{1} \log \left[\frac{\text { Revenue }_{i, t}}{\text { Revenue }_{i, t-1}}\right]+\beta_{2} * \operatorname{DECRDUM}_{i, t} * \log \left[\frac{\text { Revenue }_{i, t}}{\text { Revenue }_{i, t-1}}\right]+$

Keterangan:

$\mathrm{HPP}_{\mathrm{i}, \mathrm{t}} \quad=$ Harga pokok penjualan (HPP) perusahaan i pada periode $\mathrm{t}$.

Revenue $_{i, \mathrm{t}} \quad=$ Pendapatan penjualan bersih perusahaan i pada periode $\mathrm{t}$

$\operatorname{DECRDUM}_{i, \mathrm{t}} \quad=$ Variabel dummy periode penjualan yang bernilai 1 jika penjualan turun dan bernilai 0 jika penjualan naik

Jika HPP adalah sticky, variasi HPP dengan penjualan bersih (revenue) bertambah harus lebih besar daripada ketika penjualan bersih menurun. Koefisien $\beta_{1}$ mengukur persentase kenaikan HPP akibat kenaikan penjualan bersih sebesar 1 persen, dan penjumlahan koefisien $\beta_{1}+\beta_{2}$ mengukur persentase penurunan HPP akibat penurunan penjualan bersih sebesar 1 persen. Hipotesis 2 mendasarkan pada asumsi $\beta_{1}>0, \beta_{2}<0$, atau jika $\beta_{1}+\beta_{2}<\beta_{1}$, yang menunjukkan bahwa kenaikan HPP pada saat penjualan bersih naik lebih tinggi dibandingkan penurunan HPP pada saat penjualan bersih turun. Ini berarti HPP bersifat sticky.

\section{HASIL DAN PEMBAHASAN}

\section{Proses Pemilihan Sampel}

Penelitian ini menggunakan data laporan keuangan tahunan perusahaan manufaktur di BEI selama periode 2009-2012. Proses pemilihan sampel dapat dilihat pada Tabel 1.

Tabel 1

\section{Proses Pemilihan Sampel}

\section{Kriteria-kriteria Sampel}

Perusahaan manufaktur terdaftar di BEI tahun 2009-2012

Perusahaan manufaktur yang tidak menerbitkan laporan keuangan tahun 2009-

2012 secara terus menerus di website resmi BEI dan perusahaan manufaktur yang jumlah biaya penjualan, administrasi dan umum serta HPP melebihi jumlah pendapatan penjualan bersih

Sampel emiten

Jumlah data selama 3 tahun (2009-2012)

Outlier hipotesis 1

Outlier hipotesis 2

Total sampel data hipotesis 1

Total sampel data hipotesis 2
Jumlah Data

138 


\section{Statistik Deskriptif}

Statistik deskriptif untuk perubahan penjualan, biaya penjualan, administrasi dan umum dan HPP dari tahun 2009-2010, 2010-2011 dan 2011-2012 disajikan pada Tabel 2.

Tabel 2

\section{Statistik Deskriptif}

\begin{tabular}{|c|c|c|c|}
\hline & Rata-rata (Rp) & $\begin{array}{c}\text { Jumlah Sampel } \\
\text { yang Mengalami } \\
\text { Kenaikan } \\
\end{array}$ & $\begin{array}{c}\text { Jumlah Sampel } \\
\text { yang Mengalami } \\
\text { Penurunan } \\
\end{array}$ \\
\hline $\begin{array}{l}\text { Perubahan biaya penjualan, administrasi } \\
\text { dan umum tahun 2009-2010 }\end{array}$ & 158.877 .687 .576 & 90 & 27 \\
\hline $\begin{array}{l}\text { Perubahan biaya penjualan, administrasi } \\
\text { dan umum tahun 2010-2011 }\end{array}$ & 126.705.085.894 & 89 & 28 \\
\hline $\begin{array}{l}\text { Perubahan biaya penjualan, administrasi } \\
\text { dan umum tahun 2011-2012 }\end{array}$ & 186.492.249.418 & 96 & 21 \\
\hline $\begin{array}{l}\text { Perubahan harga pokok penjualan dari } \\
\text { tahun 2009-2010 }\end{array}$ & 532.035 .777 .629 & 87 & 30 \\
\hline $\begin{array}{l}\text { Perubahan harga pokok penjualan dari } \\
\text { tahun 2010-2011 }\end{array}$ & 782.796 .800 .037 & 100 & 17 \\
\hline $\begin{array}{l}\text { Perubahan harga pokok penjualan dari } \\
\text { tahun 2011-2012 }\end{array}$ & 637.667.253.802 & 88 & 29 \\
\hline $\begin{array}{l}\text { Perubahan penjualan dari tahun 2009- } \\
2010\end{array}$ & 623.762.334.968 & 89 & 28 \\
\hline $\begin{array}{l}\text { Perubahan penjualan dari tahun 2010- } \\
2011\end{array}$ & 1.053.334.520.714 & 101 & 16 \\
\hline $\begin{array}{l}\text { Perubahan penjualan dari tahun 2011- } \\
2012\end{array}$ & 818.486.473.954 & 87 & 30 \\
\hline
\end{tabular}

Dari Tabel 2 dapat dilihat bahwa terdapat peningkatan biaya penjualan, administrasi dan umum stabil meningkat, di mana pada periode 2009-2010 sebesar 77 persen dari total sampel dengan nilai rata-rata sebesar Rp158.877.687.576. Sedangkan pada periode 2010-2011 sebesar 76 persen dari total sampel dengan nilai rata-rata sebesar Rp126.705.085.894. Pada periode 2011-2012 sebesar 82 persen dari total sampel dengan rata-rata sebesar Rp186.492.249.418.

Dari Tabel 2 juga dapat dilihat bahwa pada periode 2009-2010 dan 20102011 terjadi peningkatan HPP yang relatif sama dengan nilai rata-rata yaitu Rp532.035.777.629 (peningkatan dialami oleh 74 persen dari total perusahaan sampel) dan Rp782.796.800.037 (peningkatan dialami oleh 85 persen dari total perusahaan sampel). Namun pada periode 2011-2012 peningkatan HPP justru menurun sebesar Rp637.667.253.802, yang dialami oleh 75 persen dari total perusahaan sampel.

Pada periode 2009-2010, 2010-2011 dan 2011-2012 terjadi peningkatan penjualan yang cukup fluktuatif, di mana pada periode 2009-2010 terdapat peningkatan penjualan dengan nilai rata-rata sebesar Rp623.762.334.968 oleh 76 
persen dari total perusahaan sampel. Periode 2010-2011 terdapat peningkatan penjualan dengan nilai rata-rata sebesar Rp1.053.334.520.714 oleh 86 persen dari total perusahaan sampel. Pada periode 2011-2012 terdapat 74 persen dari total sampel yang mengalami peningkatan penjualan dengan nilai rata-rata sebesar Rp818.486.473.954.

\section{Pengujian Hipotesis}

Sebelum dilakukan pengujian hipotesis, telah dilakukan pengujian asumsi klasik untuk memperoleh hasil model yang baik. Hasil uji asumsi klasik menunjukkan bahwa model telah lolos uji multikolinearitas, uji autokorelasi, uji heteroskedastisitas dan uji normalitas.

\section{Pengujian Hipotesis 1}

Hasil pengujian hipotesis 1 disajikan pada Tabel 3.

Tabel 3

Hasil Uji Regresi

Biaya Penjualan, Administrasi dan Umum

\begin{tabular}{ccc}
\hline \multirow{2}{*}{ Model } & \multicolumn{2}{c}{ Unstandardized Coefficients } \\
\cline { 2 - 3 } & $\beta$ & Std. Error \\
\hline Penjualan & 0,117 & 0,044 \\
Periode & $-0,068$ & 0,072 \\
\hline
\end{tabular}

Dari Tabel 3 dapat dilihat bahwa asumsi koefisien regresi $\beta_{1}>0$ dan koefisien regresi $\beta_{2}<0$ terpenuhi. Dengan menjumlahkan koefisien $\beta_{1}+\beta_{2}$ maka akan diperoleh persentase penurunan biaya penjualan, administrasi dan umum akibat penurunan penjualan bersih sebesar 1 persen, menghasilkan nilai $0,049 \quad(0,117-0,068)$. Sedangkan nilai nilai koefisien $\beta_{1}$ sebesar 0,117 . Ini berarti apabila penjualan bersih turun sebesar 1 persen maka biaya penjualan, administrasi dan umum akan turun sebesar 0,049 persen. Sedangkan bila penjualan bersih naik sebesar 1 persen maka biaya penjualan, administrasi dan umum akan naik sebesar 0,117 persen. Hal ini berarti hipotesis 1 didukung oleh hasil penelitian.

Besaran kenaikan biaya penjualan, administrasi dan umum pada saat penjualan bersih naik lebih tinggi dibanding besaran penurunan biaya penjualan, administrasi dan umum pada saat penjualan bersih turun. Hal ini berarti terdapat perilaku sticky cost pada biaya penjualan, administrasi dan umum pada perusahaan manufaktur di BEI.

Dapat dilihat pada Tabel 2 bahwa terdapat perubahan biaya penjualan, administrasi dan umum yang tidak proporsional pada periode 2009-2010 hingga periode 2010-2011, dimana terdapat peningkatan penjualan sebesar Rp429.572.185.746 dan penurunan biaya sebesar Rp32.172.601.682. Namun antara 
periode 2010-2011 hingga periode 2011-2012 terdapat penurunan penjualan sebesar Rp234.848.046.760, namun biaya justru mengalami peningkatan sebesar Rp59.787.163.524. Kondisi ini memungkinkan terjadinya inefisiensi biaya. Anderson et al. (2006) menambahkan bahwa biaya seharusnya mengikuti pergerakan penjualan secara proporsional dan bila tidak terjadi demikian maka hal ini memberikan sinyal bahwa terjadinya inefisiensi biaya yang akan mengakibatkan terdapatnya perilaku sticky cost.

Hasil penelitian ini sejalan dengan penelitian Anderson et al. (2003), De Medeiros dan Costa (2005), Teruya (2010), Weiss (2010), serta Windyastuti dan Biyanto (2005). Weiss (2010) menyatakan bahwa biaya penjualan, administrasi dan umum dikatakan sticky jika komponen terbesar dalam biaya penjualan, administrasi dan umum adalah fixed cost yang tidak mudah mengikuti pergerakan penjualan. Sehingga kenaikan biaya penjualan, administrasi dan umum ketika penjualan naik lebih besar dibandingkan dengan penurunannya pada volume aktivitas yang sama.

Komponen pembentuk biaya penjualan, administrasi dan umum antara lain biaya gaji karyawan kantor, biaya penyusutan gedung kantor dan pemeliharaan aset kantor. Penghentian karyawan kantor ketika penjualan menurun, pada perusahaan akan berakibat kekurangan tenaga kerja ketika penjualan meningkat. Hal ini membuat cost penggantian tenaga kerja atau biaya gaji karyawan kantor naik sehingga perilaku sticky cost lebih tinggi. Perilaku sticky cost juga terjadi ketika penjualan meningkat maka biaya pemeliharaan aset juga ikut meningkat seiring peningkatan kapasitas penggunaan, tetapi ketika penjualan menurun maka perusahaan pun mengeluarkan biaya pemeliharaan aset untuk mempertahankan aset jika sewaktu-waktu penjualan meningkat dan tidak mungkin dilakukan penghentian aset begitu saja (Windyastuti dan Biyanto 2005).

Penelitian ini sesuai dengan cost adjustment delay theory. Manajer yang memprediksi penjualan akan meningkat di masa depan akan mendorong manajer untuk mempertahankan sumber daya yang tidak digunakan daripada mengeluarkan biaya penyesuaian ketika permintaan menurun. Hal ini akan menimbulkan biaya tetap yang membuat total biaya sulit untuk berubah sehingga muncul indikasi perilaku sticky cost.

Contoh data sampel pada PT Gunawan Dianjaya Steel Tbk., menunjukkan bahwa ketika penjualan tahun 2010 sebesar Rp1.710.131.747.278, biaya penjualan, administrasi dan umum tahun 2010 sebesar Rp1.413.250.956.160. Ketika penjualan tahun 2011 meningkat menjadi Rp2.093.544.754.762 atau meningkat sebesar 22,420 persen, biaya penjualan, administrasi dan umum tahun 2011 juga meningkat menjadi Rp1.846.950.280.693 atau meningkat sebesar 30,688 persen. Ketika penjualan tahun 2012 menurun menjadi Rp1.647.928.004.308 atau menurun sebesar 21,285 persen, biaya penjualan, administrasi dan umum tahun 2012 menurun menjadi Rp1.512.090.652.332 atau menurun sebesar 18,130 persen. Hal ini menunjukkan 
bahwa penurunan biaya penjualan, administrasi dan umum tidak sebanding dengan peningkatan biaya penjualan, administrasi dan umum pada tahun sebelumnya ketika penjualan naik.

\section{Pengujian Hipotesis 2}

Hasil pengujian hipotesis 2 disajikan pada Tabel 4.

Tabel 4

Hasil Uji Regresi Harga Pokok Penjualan

\begin{tabular}{lcc}
\hline \multirow{2}{*}{ Model } & \multicolumn{2}{c}{ Unstandardized Coefficients } \\
\cline { 2 - 3 } & $\boldsymbol{\beta}$ & Std. Error \\
\hline Penjualan & 1,063 & 0,098 \\
Periode & $-1,030$ & 0,131 \\
\hline
\end{tabular}

Dari tabel di atas dapat dilihat bahwa asumsi koefisien regresi $\beta_{1}>0$ dan koefisien regresi $\beta_{2}<0$ terpenuhi. Dengan menjumlahkan koefisien $\beta_{1}+\beta_{2}$ maka akan diperoleh persentase penurunan HPP akibat penurunan penjualan bersih sebesar 1 persen, menghasilkan nilai 0,033 (1,063-1,030). Sedangkan nilai nilai koefisien $\beta_{1}$ sebesar 1,063. Ini berarti apabila penjualan bersih turun sebesar 1 persen, maka HPP akan turun sebesar 0,033 persen. Sedangkan bila penjualan bersih naik sebesar 1 persen maka harga pokok penjualan akan naik sebesar 1,063 persen. Hal ini berarti hipotesis 2 didukung dengan hasil penelitian. Besaran kenaikan HPP pada saat penjualan bersih naik lebih tinggi dibanding besaran penurunan HPP pada saat penjualan bersih turun. Hal ini berarti terdapat perilaku sticky cost pada HPP pada perusahaan manufaktur di BEI.

Dapat dilihat pada Tabel 2 bahwa terdapat perubahan HPP yang tidak proporsional pada periode 2009-2010 hingga periode 2010-2011, dimana terdapat peningkatan penjualan sebesar Rp429.572.185.746 dan peningkatan HPP sebesar Rp 250.761.022.408. Namun antara periode 2010-2011 hingga periode 2011-2012 terdapat penurunan penjualan sebesar Rp234.848.046.760 dan penurunan HPP sebesar Rp145.572.185.746. Hal ini memungkinkan terjadinya ketidakseimbangan antara HPP dan volume aktivitas penjualan. Anderson et al. (2006) menambahkan bahwa biaya seharusnya mengikuti pergerakan penjualan secara proporsional dan bila tidak terjadi demikian maka hal ini memberikan sinyal bahwa terjadinya inefisiensi biaya yang akan mengakibatkan terdapatnya perilaku sticky cost.

Hasil penelitian ini sejalan dengan penelitian Weidenmier dan Subramaniam (2003), dimana sticky cost pada HPP terjadi karena adanya ketidakseimbangan antara perubahan peningkatan HPP dan perubahan penurunan HPP atas dasar perubahan volume aktivitas penjualan pada saat mengalami peningkatan maupun penurunan. Dalam penelitian Weiss (2010), HPP dikatakan sticky ketika permintaan meningkat, karena manajer akan memutuskan untuk menambah kapasitas produksi sejalan dengan elemen-elemen pembentuk HPP yang juga akan meningkat. Sebaliknya 
ketika permintaan menurun, maka manajer akan meminimalkan biaya produksi, tetapi tidak seluruh biaya akan turun mengikuti aktivitas produksi.

HPP pada penelitian ini dihitung dengan menggunakan metoda full costing, yang memasukkan seluruh komponen biaya produksi sebagai unsur harga pokok baik yang bersifat variabel maupun tetap. Biaya produksi terdiri dari biaya bahan baku langsung, biaya tenaga kerja langsung dan biaya overhead pabrik. Ketika terjadi kenaikan atau penurunan permintaan, manajer mudah untuk melakukan penyesuaian terhadap biaya bahan baku langsung dan biaya tenaga kerja langsung karena kedua biaya tesebut bersifat variabel mengikuti perubahan jumlah produksi. Sedangkan biaya overhead tidak mudah untuk disesuaikan mengingat sebagian besar biaya overhead bersifat tetap. Sebagai contoh ketika perusahaan mengalami peningkatan permintaan, maka perusahaan akan menambah jumlah mesin produksi sekaligus asuransi atas mesin tersebut, menambah biaya pemeliharaan mesin bahkan memperluas area pabrik. Ketika permintaan turun, manajer tetap akan mendepresiasi pabrik, membayar asuransi mesin produksi dan melakukan pemeliharaan mesin produksi untuk mengantisipasi kenaikan permintaan di periode berikutnya. Komponen HPP yang bersifat tetap inilah yang membuat HPP bersifat sticky.

Penelitian ini mendukung cost adjustment delay theory. Pertimbangan pribadi manajer yang memprediksi penjualan akan meningkat di masa depan mendorong manajer untuk mempertahankan sumber daya yang tidak digunakan daripada mengeluarkan biaya penyesuaian ketika permintaan menurun. Hal ini akan menimbulkan biaya tetap yang membuat total biaya sulit untuk berubah, sehingga muncul indikasi perilaku sticky cost.

Contoh data sampel pada PT Indo Kordsa Tbk., menunjukkan bahwa ketika penjualan tahun 2010 sebesar Rp1.805.359.612.000, HPP tahun 2010 adalah sebesar Rp1.497.478.944.000. Ketika penjualan tahun 2011 meningkat menjadi Rp1.967.727.553.684 atau meningkat sebesar 8,993 persen, HPP tahun 2011 juga meningkat menjadi Rp1.720.105.555.772 atau meningkat sebesar 14,866 persen. Ketika penjualan tahun 2012 menurun menjadi Rp1.683.896.841.260 atau menurun sebesar 14,424 persen, HPP tahun 2012 menurun menjadi Rp1.544.553.717.470 atau menurun sebesar 10,205 persen. Hal ini menunjukkan bahwa penurunan HPP tidak sebanding dengan peningkatan HPP pada tahun sebelumnya ketika penjualan naik.

\section{SIMPULAN}

Berdasarkan hasil uji hipotesis pertama yang telah dilakukan, disimpulkan bahwa terdapat indikasi perilaku sticky cost pada biaya penjualan, administrasi dan umum pada perusahaan manufaktur di Bursa Efek Indonesia. Hal ini sesuai dengan penelitian Anderson et al. (2003), De Medeiros dan Costa (2005), Teruya (2010), Weiss (2010) serta Windyastuti dan Biyanto (2005) yang menyatakan bahwa besarnya kenaikan biaya penjualan, administrasi dan umum pada saat penjualan 
bersih naik lebih tinggi dibanding besaran penurunan biaya penjualan, administrasi dan umum pada saat penjualan bersih turun. Hasil penelitian ini tidak sejalan dengan penelitian Nugroho dan Endarwati (2013) yang menemukan bahwa tidak terdapat indikasi perilaku sticky cost pada perusahaan manufaktur di Indonesia

Berdasarkan analisis hasil uji hipotesis kedua yang telah dilakukan, disimpulkan bahwa terdapat indikasi perilaku sticky cost pada HPP pada perusahaan manufaktur di Bursa Efek Indonesia. Hal ini sesuai dengan penelitian Weidenmier dan Subramaniam (2003) yang menyatakan bahwa besarnya kenaikan HPP pada saat penjualan bersih naik lebih tinggi dibanding besaran penurunan HPP pada saat penjualan bersih turun. Hasil penelitian ini tidak sejalan dengan Hidayatullah et al. (2011) yang tidak menemukan indikasi perilaku sticky cost pada HPP.

Hasil pengujian kedua hipotesis mendukung cost adjustment delay theory. Pertimbangan pribadi manajer yang memprediksi penjualan akan meningkat di masa depan, mendorong manajer untuk mempertahankan sumber daya yang tidak digunakan daripada mengeluarkan biaya penyesuaian ketika permintaan menurun. Hal ini akan menimbulkan biaya tetap yang membuat total biaya sulit untuk berubah sehingga muncul indikasi perilaku sticky cost.

Implikasi terapan dari penelitian ini adalah dengan adanya bukti indikasi perilaku sticky cost pada perusahaan manufaktur di Indonesia menunjukkan bahwa perubahan biaya tidak selalu mengikuti perubahan tingkat aktivitas. Hal ini dimungkinkan karena manajer yang kurang mampu menyesuaikan biaya dengan baik berdasarkan pergerakan aktivitas penjualan pada saat meningkat maupun menurun. Selanjutnya diharapkan manajer dapat mempertimbangkan kembali pengambilan keputusan dan perencanaan biaya pada batas mana sticky cost masih bisa dibiarkan dan pada batas mana biaya harus mulai disesuaikan agar biaya dapat dikelola sedemikian rupa sehingga tingkat sticky pada perusahaan tidak meningkat.

Pada penelitian ini komponen biaya administrasi, penjualan dan umum serta HPP dilihat secara total. Untuk penelitian selanjutnya diharapkan agar melihat biaya penjualan, administrasi dan umum serta HPP lebih dalam lagi ke dalam beberapa kelompok biaya misalnya seperti komponen biaya gaji, upah dan tunjangan, perbaikan dan pemeliharaan aset kantor maupun pabrik serta biaya sewa. Hal ini agar dapat melihat kelompok biaya mana yang paling signifikan memengaruhi perilaku sticky cost.

Dapat dilakukan pula pengembangan penelitian mengenai perilaku sticky cost pada perusahaan selain sektor manufaktur, seperti sektor keuangan, pertanian, pertambangan, perdagangan, jasa dan investasi. Hal ini agar bermanfaat bagi pengembangan penelitian mengenai perilaku sticky cost dan menambah keluasan literatur mengenai biaya bagi dunia ekonomi dan bisnis. 


\section{DAFTAR PUSTAKA}

Anderson, M. C., R. D. Banker, dan S. N. Janakiraman. 2003. Are selling, general, and administrative cost "sticky"? Journal of Accounting Research. Vol.41 No.1.

Anderson, M. C., R. D. Banker, R. Huang, dan S. N. Janakiraman. 2006. Cost behavior and fundamental analysis of selling, general \& administrative costs. Management Accounting Section Meeting Paper.

Argiles, J. M., dan Blandon J. G. 2009. Cost revisited: empirical application for farms. Journal of Finance and Accounting. Vol.38 No.144: 579-605.

Balakrishnan, R., E. Labro, dan N. S. Soderstrom. 2011. Cost structure and sticky cost. Working paper. Available at http://ssrn.com.

Banjer, R., dan L. Chen. 2006. Predicting earnings using a model of cost stickiness. The Accounting Review. No.78: 285-307.

Cooper, R., dan R. Kaplan. 1998. The Design Of Cost Management Systems: Text, Cases, And Readings. Upper Saddle River, NJ: Prentice Hall.

De Medeiros, O. R., dan P. D. Z. Costa. 2004. Cost stickiness in Brazilian firm. Available at $h t t p: / / p a p e r s . s s r n$.

Ghozali, I. 2006. Aplikasi Analisis Multivariate Dengan Program SPSS. Semarang: Badan Penerbit Undip.

Hidayatullah, I. J. 2011. Analisis perilaku sticky cost dan pengaruhnya terhadap prediksi laba menggunakan model cost variability dan cost stickiness pada emiten di BEI untuk industri manufaktur. Simposium Nasional Akuntansi. Available at sna.akuntansi.unikal.ac.id.

Malcom, R. E. 1991. Overhead control implications of activity costing. Accounting Horizons (December): 69-78.

Melina, M. I. 1997. Penerapan metoda harga pokok proses dan analisis titik impas perusahaan kecap cap "WM" di Surabaya Jawa Timur. Skripsi. Institut Pertanian Bogor.

Mulyadi. 2005. Akuntansi Biaya. Edisi ke-5 Cetakan ke-8. Yogyakarta: Aditya Media.

Nugroho, P. I., dan W. Endarwati. 2013. Do the cost stickiness in the selling, general and administrative costs occur in manufacturing companies in Indonesia? Simposium Nasional Akuntansi XVI Manado.

Setiawan, H. 2008. Penerapan perhitungan harga pokok produksi dalam kaitannya dengan pelaporan keuangan pada PT Alas Seni Kreasi Industri. Jurnal Ilmiah Kesatuan. Vol.1 No.10. 
Teruya, J., T. Shimizu, dan D. He. 2010. Sticky selling, general, and administrative cost behavior and it's changes in Japan. Global Journal of Business Research. Vol.4 No.4.

Weidenmier, M. L., dan C. Subramaniam. 2003. Additional evidence on the sticky behavior of costs. Working paper. Texas Christian University. Available at http://dx.doi.org.

Weiss, D. 2010. Cost behavior and analysts' earnings forecast. The Accounting Review. Vol.85 No.4.

Windyastuti, B. F. 2005. Analisis perilaku cost: Perilaku sticky cost cost pemasaran, administrasi \& umum pada penjualan bersih (studi empiris perusahaan yang terdaftar di BEJ). Simposium Nasional Akuntansi VIII, Solo.

Yasukata, K., dan T. Kajiwara. 2011. Are "sticky costs" the result of deliberate decision of managers?. Working paper Kobe University, Kobe, Japan. 